\title{
Article \\ Chemoenzymatic Synthesis and Antibody Binding of HIV-1 V1/V2 Glycopeptide-Bacteriophage $Q \beta$ Conjugates as a Vaccine Candidate
}

\author{
Guanghui Zong ${ }^{\dagger}\left(\mathbb{D}\right.$, Christian Toonstra $^{\dagger}$, Qiang Yang, Roushu Zhang and Lai-Xi Wang * \\ Department of Chemistry and Biochemistry, University of Maryland, College Park, MD 20742, USA; \\ gzong@umd.edu (G.Z.); toonstrac@gmail.com (C.T.); qyang1@umd.edu (Q.Y.); rzhang17@umd.edu (R.Z.) \\ * Correspondence: wang518@umd.edu; Tel.: +1-301-405-7527 \\ + Equal contributions as co-first authors.
}

check for

updates

Citation: Zong, G.; Toonstra, C.; Yang, Q.; Zhang, R.; Wang, L.-X. Chemoenzymatic Synthesis and Antibody Binding of HIV-1 V1/V2 Glycopeptide-Bacteriophage $\mathrm{Q} \beta$ Conjugates as a Vaccine Candidate. Int. J. Mol. Sci. 2021, 22, 12538. https://doi.org/10.3390/ ijms222212538

Academic Editor: Alexander O. Chizhov

Received: 26 October 2021 Accepted: 19 November 2021 Published: 21 November 2021

Publisher's Note: MDPI stays neutral with regard to jurisdictional claims in published maps and institutional affiliations.

Copyright: (c) 2021 by the authors. Licensee MDPI, Basel, Switzerland. This article is an open access article distributed under the terms and conditions of the Creative Commons Attribution (CC BY) license (https:/ / creativecommons.org/licenses/by/ $4.0 /)$.

\begin{abstract}
The broadly neutralizing antibody PG9 recognizes a unique glycopeptide epitope in the V1V2 domain of HIV-1 gp120 envelope glycoprotein. The present study describes the design, synthesis, and antibody-binding analysis of HIV-1 V1V2 glycopeptide-Q $\beta$ conjugates as a mimic of the proposed neutralizing epitope of PG9. The glycopeptides were synthesized using a highly efficient chemoenzymatic method. The alkyne-tagged glycopeptides were then conjugated to the recombinant bacteriophage $(\mathrm{Q} \beta)$, a virus-like nanoparticle, through a click reaction. Antibody-binding analysis indicated that the synthetic glycoconjugates showed significantly enhanced affinity for antibody PG9 compared with the monomeric glycopeptides. It was also shown that the affinity of the $Q \beta$ conjugates for antibody PG9 was dependent on the density of the glycopeptide antigen display. The glycopeptide- $\mathrm{Q} \beta$ conjugates synthesized represent a promising candidate of HIV-1 vaccine.
\end{abstract}

Keywords: glycopeptide; glycoconjugate; neutralizing epitope; bacteriophage $\mathrm{Q} \beta$; neutralizing antibody; HIV vaccine

\section{Introduction}

A protective vaccine is the best hope to combat the global epidemic of HIV / AIDS. Despite tremendous efforts, an effective immunogen capable of eliciting long-lasting, broadly neutralizing antibodies (bNAbs) has yet to be realized [1-10]. HIV-1 has evolved a number of defense mechanisms, including frequent sequence variation and heavy glycosylation, to evade host immune surveillance [7,11,12]. For a long time, $2 \mathrm{G} 12$ that targets a cluster of high-mannose $\mathrm{N}$-glycans in gp120 was the only carbohydrate-specific broadly neutralizing antibody available for HIV vaccine research [13-17]. However, in the last decade, a new class of glycan-reactive broadly neutralizing antibodies (bNAbs), represented by PG9, PG16, PGT121, PGT128, and PGT135 has been discovered, which appear to target conserved $N$-glycans and peptide as integral epitopes in the V1V2 and V3 regions [18-24]. These antibodies neutralize various HIV-1 primary strains with remarkable breadth and potency (up to 100-fold more potent than the prototype neutralizing antibodies such as 2G12 and 4E10). The discovery of this entirely new class of glycan-reactive bNAbs has raised new hopes and provided an enormous impetus to HIV vaccine research.

As the first step for an effective immunogen design, we recently applied a chemoenzymatic synthetic approach to characterize the glycan specificity and minimal glycopeptide neutralizing epitopes of the PG9, PGT128, PGT121, and 10-1074 bNAbs [25,26]. We synthesized a series of V1V2 glycopeptides with well-defined N-glycans at the conserved N160 and N156 (CAP45 strain) or N173 (ZM 109 strain) glycosylation sites. The study led to the identification of a cyclic glycopeptide carrying a Man ${ }_{5} \mathrm{GlCNAc}_{2}$ glycan and a sialylated complex type N-glycan at the N160 and N156/N173 sites as the minimal epitope for PG9 [25]. More recently, we synthesized a library of HIV-1 V3 glycopeptides derived from HIV-1 
JR-FL strain and performed antibody binding studies, which identified a 33-mer mini-V3 glycopeptide carrying a high-mannose $\mathrm{N}$-glycan at the N332 site as the epitope of bNAbs PGT128 and 10-1074, and the mini-V3 glycopeptide carrying a sialylated complex type $\mathrm{N}$-glycan at the N301 site as a possible epitope for PGT121 [26]. Moreover, we designed and synthesized a self-adjuvant three-component immunogen that consists of the 33-mer V3 glycopeptide epitope and its trimeric form, a universal T-helper epitope P30, and a lipopeptide $\left(\mathrm{Pam}_{3} \mathrm{CSK}_{4}\right)$ that is a ligand of Toll-like receptor 2 for stimulating immune response [27-30]. It was shown for the first time that the synthetic three-component glycopeptide immunogens can elicit glycan-dependent antibodies in a relatively short period of time. In addition, sera antibodies induced by the glycopeptide immunogen exhibited broad recognition of several HIV-1 gp120s across clades [27-30]. Independently, Haynes and coworkers have also reported that a 30-mer synthetic mini-V3 glycopeptide derived from the JR-FL strain, when formulated in the Toll-like receptor 4 agonist GLA-SE adjuvant, can induce V3-glycan targeted antibodies in rhesus macaques, although the monomeric V3 glycopeptide lacking T-helper epitopes are weakly immunogenic require high-dose and long repeated immunization to raise glycan-specific antibodies [31,32]. Despite these encouraging immunization results, the synthesis of the three-component glycopeptide immunogens takes multiple steps and is not easy to make. On the other hand, there are apparent advantages to use the virus-like particle (VLP), bacteriophage $\mathrm{Q} \beta$, as a platform to design epitope-based vaccines $[33,34]$. The rigid and highly repetitive surface pattern permits highly ordered display of multiple copies of the glycopeptide epitopes, which could facilitate cross-linking of B-cell receptors and promote B cell activation. The highly repetitive pattern of epitope presentation on $Q \beta$ may also enhance the avidity of the neutralizing epitopes for germ-line B cell receptors associated with the bNAbs, which is particularly important for HIV-1 vaccine design [35-37]. In comparison with gp120 and its modified derivatives that contain numerous non-neutralizing epitopes, the pure glycopeptide-based immunogen could focus immune responses to the glycopeptide neutralizing epitopes. Moreover, recent electron microscopy studies have suggested that the PG9, as other PG series bNAbs, is trimer-preferring, targeting an epitope at the apex of the gp120 trimer that spans across two monomers, as a second N160 glycan on a neighboring protomer was involved in PG9 recognition [38]. Thus, a vaccine design should consider the quaternary structure as an important factor for conjugate vaccine design. We reasoned that multivalent display of manifold, properly defined, glycopeptides on bacteriophage $\mathrm{Q} \beta$ could have a chance to generate mimic of the quaternary structure of the glycopeptide epitopes. Indeed, bacteriophage $\mathrm{Q} \beta$ has been successfully used as a carrier protein for carbohydrate-based cancer vaccine design [39-42]. Oligomannose- $\mathrm{Q} \beta$ conjugates have been synthesized before aiming to raise 2G12-like antibodies [43]. In this paper, we report the first chemoenzymatic synthesis of an array of V1V2 glycopeptide- $Q \beta$ conjugates. Binding studies indicated that the conjugates carrying structurally well-defined $\mathrm{N}$-glycans showed potent affinity for broadly neutralizing antibody PG9, which are comparable or superior to the affinity with native HIV-1 gp120. The results suggest that the synthetic conjugates may serve as a valuable HIV vaccine candidate for raising HIV-1 glycopeptide-specific antibodies.

\section{Results and Discussion}

\subsection{Chemoenzymatic Synthesis of Alkyne-Tagged HIV-1 V1V2 Glycopeptides}

We have previously identified a cyclic glycopeptide epitope derived from the HIV-1 ZM109 strain carrying a Man ${ }_{5} \mathrm{GlNNAc}_{2}$ and a sialylated complex type N-glycan at the N160 and N173 site, respectively, as a minimal neutralizing epitope that demonstrate the specificity for antibody PG9, which demonstrate a $\mu \mathrm{M}$-level affinity for the Fab domain of the antibody [25]. We chose this glycopeptide structure as the epitopic subunit and sought to introduce an alkyne moiety at the $\mathrm{N}$-terminus of the peptide sequence for later stage $\mathrm{Q} \beta$ conjugation through a click reaction. The precursor GlcNAc-peptides were synthesized through microwave-assisted solid-phase peptide synthesis (MW-SPPS) using Fmoc chemistry on Rink Amide Resin. To install different glycans at the N160 
and N173 sites, two orthogonally protected GlcNAc-Asn building blocks, i.e., acid-labile Fmoc-Asn(DEIPS ${ }_{3}$ GlcNAc)-OH building block (1) and base-labile Fmoc-Asn-( $\mathrm{Ac}_{3} \mathrm{GlcNAc}$ )$\mathrm{OH}$ building block (2) were installed at the predetermined $N$-glycosylation site N160 and N173, respectively, following our previously reported procedure [44] (Scheme 1). Global deprotection and simultaneous release of the peptide from the resin by treatment with cocktail $\mathrm{R}$ gave the precursor peptide (3), in which the silyl protection groups on the GlcNAc at position N160 was simultaneously removed, while the GlcNAc at N173 remained protected as the $\mathrm{O}$-acetylated form. Cyclization via a disulfide bond formation between the two cysteine residues was achieved by treating 3 with 10\% DMSO in water yielded cyclic GlcNAc-peptide 4 that are ready for introduction of two different $N$-glycans at the N160 and N173 sites. Removal of the O-acetyl groups from the remaining protected GlcNAc moiety with $2.5 \%$ aqueous hydrazine gave the peptide with two free GlcNAc acceptor sites (5). The di-GlcNAc peptide 5 was also obtained by direct treatment of peptide precursor 3 with $2.5 \%$ aqueous hydrazine to remove the $O$-acetyl groups from the GlcNAc moiety, which also led to simultaneous cyclization. The GlcNAc peptides were purified by reverse-phase HPLC (RP-HPLC). The purity and identity of the GlcNAc peptides were analyzed by RP-HPLC and ESI-MS (Supplementary Information, Figures S1-S4).

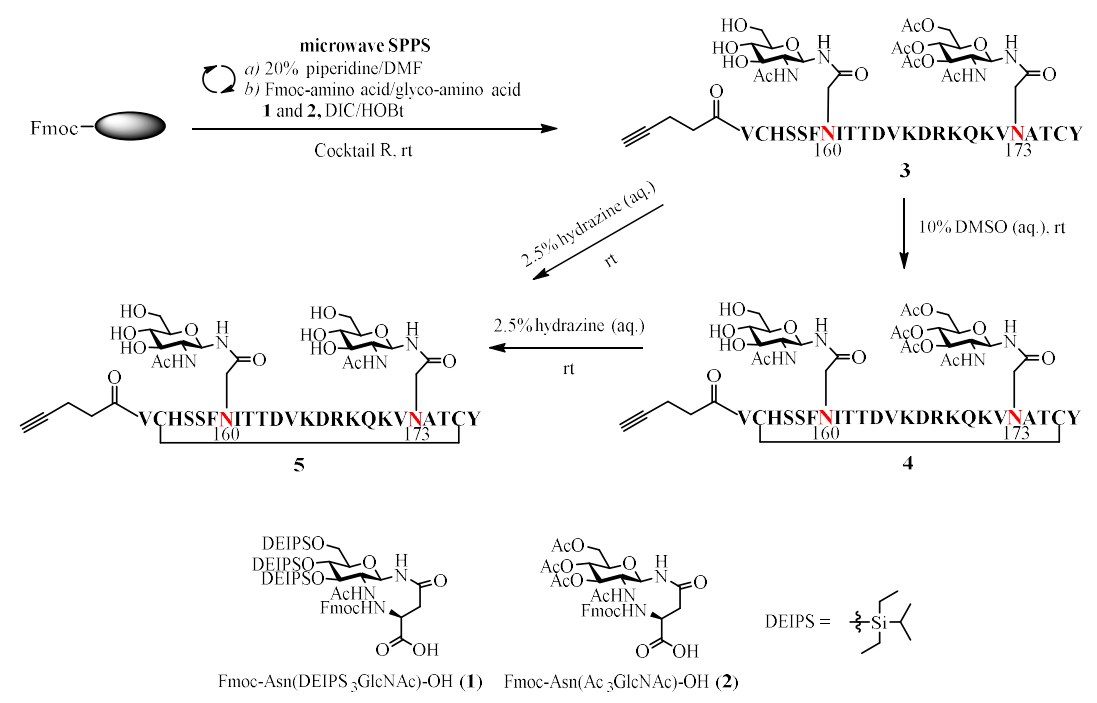

Scheme 1. Synthesis of HIV-1 V1V2 GlcNAc peptides $(3,4,5)$ through solid-phase peptide synthesis.

\subsection{Chemoenzymatic Synthesis of the HIV-1 V1V2 Glycopeptides}

With the selectively protected GlcNAc-peptides in hands, we first sought to introduce

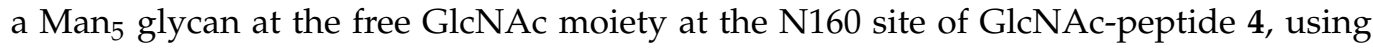
EndoM-N175Q mutant as the enzyme [45]. Thus, glycosylation of GlcNAc-peptide 4 with the Man ${ }_{5}$ GlcNAc oxazoline 6 under the catalysis of EndoM-N175Q gave glycopeptide 7 carrying a Man 5 glycan at the N160 site in excellent yield. The acetylated GlcNAc at the N173 position was then deprotected by treatment with $2.5 \%$ aqueous hydrazine, yielding glycopeptide 8 with the free GlcNAc moiety at the N173 site. Finally, a sialylated complex-type (SCT) N-glycan was installed on the free GlcNAc moiety by glycosylation with SCT-oxazoline 9 under the catalysis of EndoM-N175Q to give the doubly glycosylated peptide (10). To introduce two Man ${ }_{5}$ GlcNAc glycans in the peptide, 8 was glycosylated with the Man ${ }_{5}$ GlcNAc oxazoline 6 by EndoM-N175Q, giving the glycopeptide (11) carrying two $\mathrm{Man}_{5}$ glycans at both sites. Alternatively, glycosylation of GlcNAc-peptide (5) with excess of Man 5 GlcNAc oxazoline 6 under the catalysis of EndoM-N175Q- also gave glycopeptide 11 in good yield (Scheme 2). The transglycosylation products were purified by HPLC, and the purity and identity were confirmed by ESI-MS analysis (Figure 1; Supplementary Information, Figures S5-S8). 


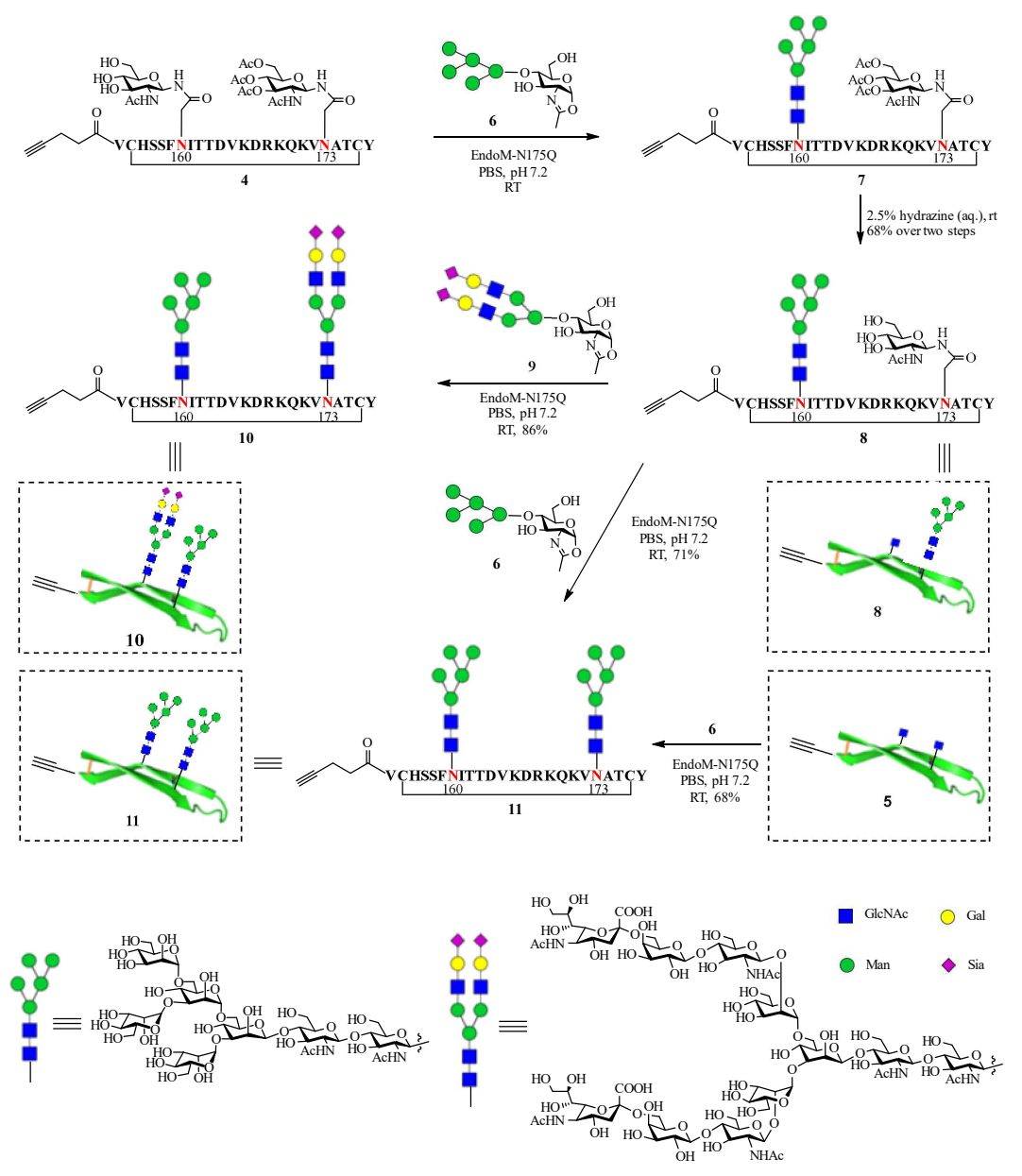

Scheme 2. Chemoenzymatic synthesis of HIV-1 V1V2 glycopeptides $(\mathbf{8}, \mathbf{1 0}, \mathbf{1 1})$.
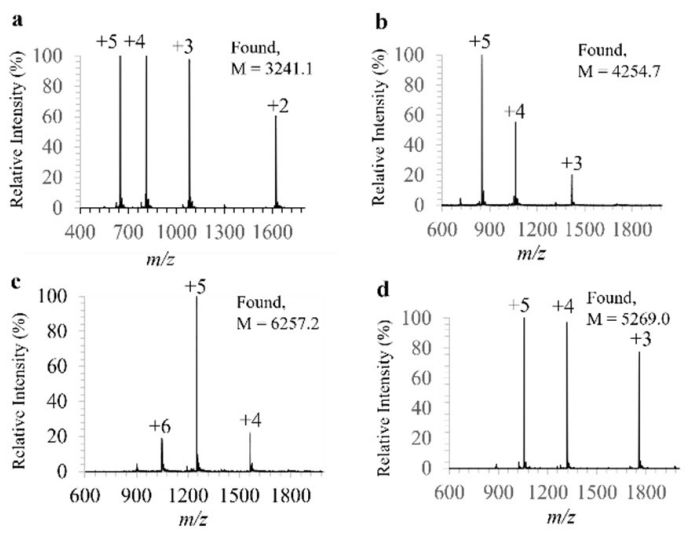

Figure 1. ESI-MS analysis of the synthetic glycopeptides. (a) glycopeptide 5; (b) glycopeptide 8; (c) glycopeptide 10; (d) glycopeptide 11.

\subsection{Synthesis and Characterization of $Q \beta-V 1 V 2$ Glycopeptide Conjugates}

We initiated the $\mathrm{Q} \beta$-V1V2 glycopeptide conjugates preparation by functionalization of wild type $Q \beta$ with azido group. Firstly, we fully functionalized the lysine amines on $Q \beta$ with a 5-carbon azido group by reaction with succinimidyl 5-azidovalerate, followed by ligation of the alkyne-tagged glycopeptides to the $\mathrm{Q} \beta-\left(5 \mathrm{C}-\mathrm{N}_{3}\right)_{720}$ via the copper-catalyzed azide-alkyne cycloaddition (CuAAC) reaction. However, the obtained $\mathrm{Q} \beta$-V1V2 glycopeptide conjugates, especially the ones carrying large size glycopeptides (with two glycans) are liable to precipitation, if stored at $4{ }^{\circ} \mathrm{C}$ over a few days. The precipitation issue was not much applied to the conjugate with smaller glycopeptides (with one glycan or only 
GlcNAc). We speculated the reason for the poor stability of the conjugate might be, on one hand, the significant physical property changes of $Q \beta$ caused by modification with a big molecule (M.W. of 10: $6.3 \mathrm{~K}$, compared to $14 \mathrm{~K}$ for $\mathrm{Q} \beta$ subunit); on the other hand, the overall lipophilicity increased dramatically by transforming the free amines on wild type $\mathrm{Q} \beta$ to triazoles after functionalization and ligation. To solve the problems, we replaced the lipophilic 5C-azide linker to a more hydrophilic polyethylene glycol (PEG) linker to increase the solubility in water. Meanwhile, we decreased the azide loading to keep around half of the lysine amines free to better maintain the physical property of $\mathrm{Q} \beta$. As shown in Scheme 3, functionalization of wild type $\mathrm{Q} \beta$ (12) with $\mathrm{N}_{3}-\mathrm{PEG}_{3}-\mathrm{NHS}$ (13) to get $\mathrm{Q} \beta-\mathrm{PEG}_{3}$ $\mathrm{N}_{3}$ with an average azide loading of 360 (estimated by MALDI-TOF analysis). Incubation of $\mathrm{Q} \beta-\mathrm{PEG}_{3}-\mathrm{N}_{3}$ with alkyne-tagged V1V2 glycopeptides $(5,8,10,11)$ via CuAAC yielded the corresponding $\mathrm{Q} \beta$-V1V2 glycopeptide conjugates 17-20 (Scheme 3). 10\% of sucrose was added in the CuAAC incubation to avoid potential protein aggregation [46]. The glycopeptide loading level was controlled by the amount of alkyne-tagged glycopeptides used (ratio of glycopeptides/subunit) and the incubation time. To get a high loading of the glycopeptides onto $Q \beta$ (1-2 glycopeptides/subunit), 3-5 eq of alkyne-tagged glycopeptides were used, and the incubation was last for up to $24 \mathrm{~h}$. The unreacted azido groups on $\mathrm{Q} \beta$ capsids were capped using a large excess of 4-pentyn-1-ol (16) by a second CuAAC reaction. The $\mathrm{Q} \beta$-V1V2 glycopeptide conjugates were purified by dialysis (MWCO 300K membrane) against $150 \mathrm{mM}$ PBS buffer.
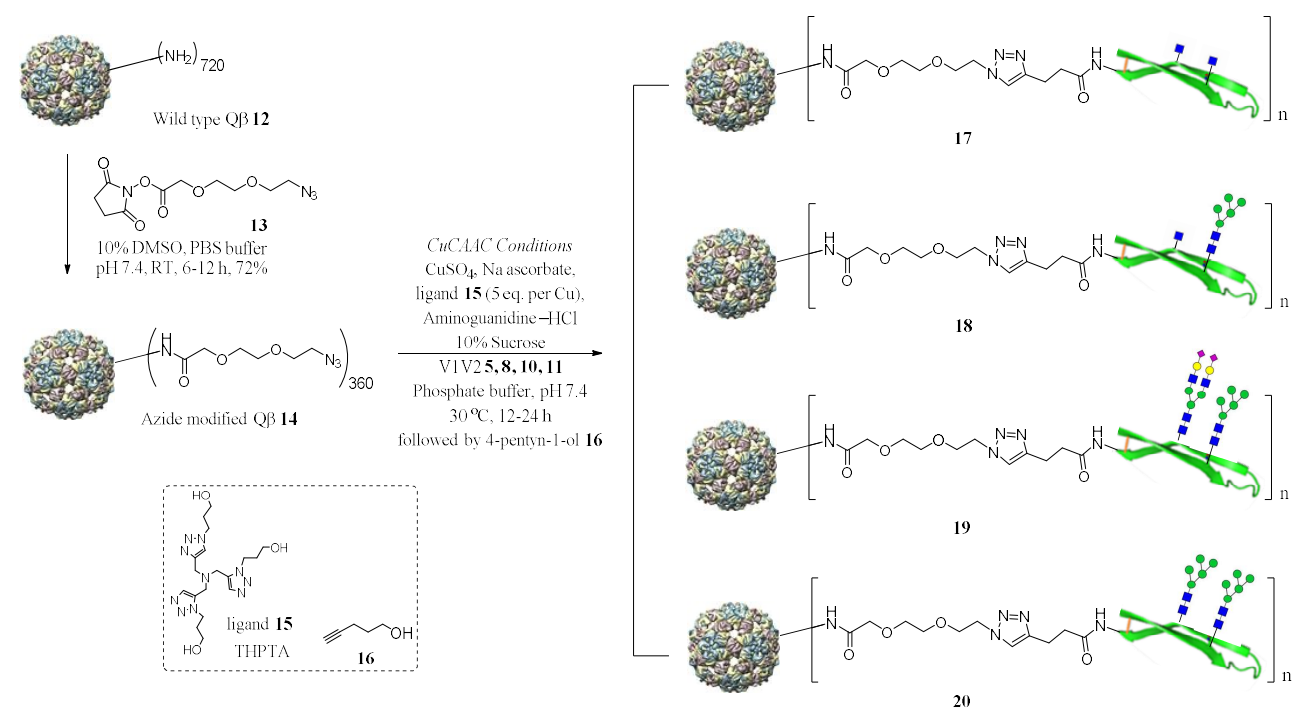

Scheme 3. Synthesis of $\mathrm{Q} \beta-\mathrm{V} 1 \mathrm{~V} 2$ glycopeptide conjugates 17-20.

To determine the glycopeptides loading, we performed both MALDI-TOF MS analysis and SDS-PAGE quantification. Overall, MALDI-TOF MS and SDS-PAGE analysis gave a similar estimate of the glycopeptide loading ratios (Figure 2). SDS-PAGE analysis exhibited the average numbers of (glyco)peptides attached onto $Q \beta$ were 282, 265, 155 and 150 for conjugates 17, 18, 19 and 20, respectively (Figure 2e, 2a, 2c and 2f, respectively). 
a. conjugate 18 , high loading, $n=282$
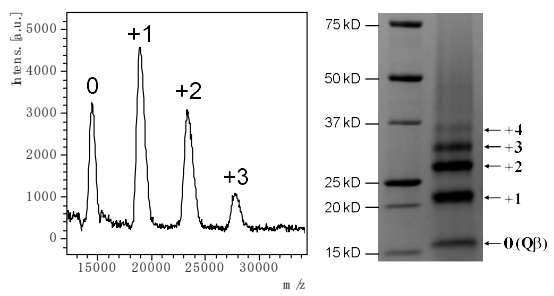

c. conjugate 19 , high loading, $n=155$
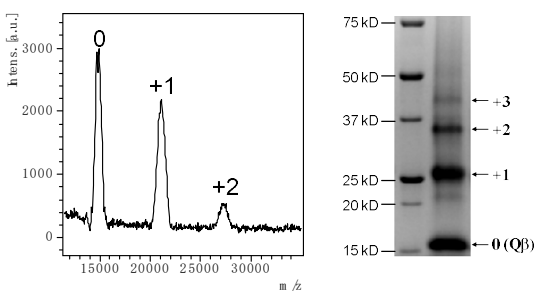

e. conjugate $17, n=265$
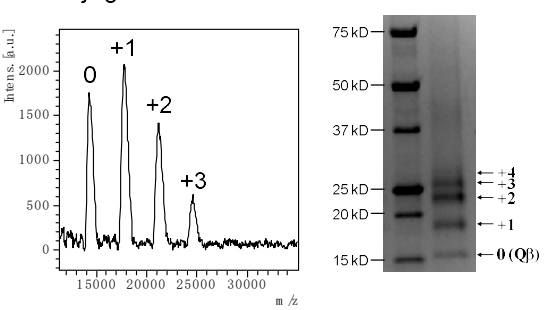

b. conjugate 18 , low loading, $n=108$

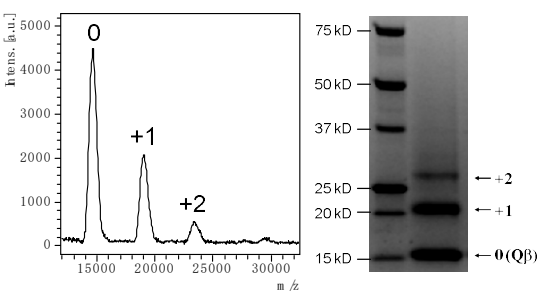

d. conjugate 19, low loading, $n=33$
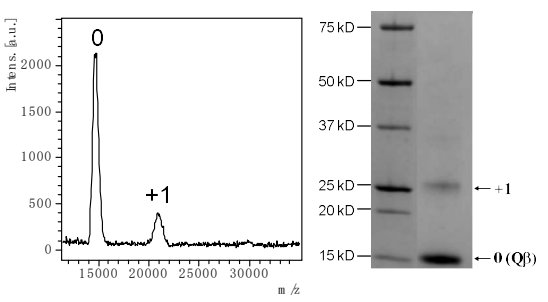

f. conjugate $20, n=150$

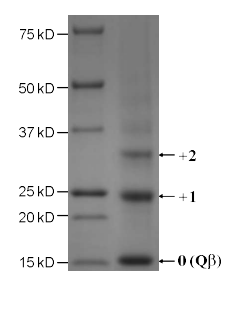

Figure 2. MALDI-TOF MS and reducing SDS-PAGE analysis of $\mathrm{Q} \beta-\mathrm{V} 1 \mathrm{~V} 2$ glycopeptide conjugates 17-20 (a), conjugate 18 with high loading; (b), conjugate 18 with low loading; (c), conjugate 19 with high loading; (d), conjugate 19 with low loading; (e), conjugate 17 with high loading; (f), conjugate 20 with high loading.

\subsection{Binding of the Synthetic Conjugates with Antibody PG9}

To assess the binding of the synthetic glycopeptide-Q $\beta$ conjugates to antibody PG9, we used conventional ELISA and compared the binding with HIV-1 gp120 envelope glycoproteins from clade M, strain M.CON-S (gp120 M.CON-S) and AE.A244.

Antigenicity of the conjugates was found to be highly dependent upon glycosylation, as conjugates bearing two GlcNAc alone (17, Q $\beta$-Gn-Gn) yielded no recognition by PG9 (Figure 3), whereas the conjugates bearing one or two glycans $(\mathbf{1 8}, \mathbf{1 9}, \mathbf{2 0})$ substantially increased the binding affinity. As a negative control, nonconjugated $\mathrm{Q} \beta$ did not show affinity for PG9. The results suggest that the nonglycosylated V1V2 peptides is insufficient for significant binding affinity by PG9, even in a multivalent context. The finding is in an agreement with the results of PG9 binding to monovalent peptides containing GlcNAc alone, reported previously by our group and others [25,44,47]. The previous reports indicated no binding affinity by PG9 for nonglycosylated putative V1V2 peptides.

The addition of a single $\mathrm{Man}_{5} \mathrm{GlcNAc}_{2}$ glycan (conjugate 18) significantly increased the binding affinity by PG9 $\left(\mathrm{EC}_{50}=\sim 12.4 \mathrm{nM}\right.$, Figure $\left.3, \mathrm{Q} \beta-\mathrm{M} 5-\mathrm{Gn}, \mathrm{HL}\right)$, compared to its nonglycosylated V1V2 peptide- $Q \beta$ counterpart (conjugate 17), suggesting that the glycan at N160 site is crucial for the PG9 recognition. The conjugate bearing both glycans (19, Figure 3, Q $\beta$-M5-SCT, HL), i.e., $\mathrm{Man}_{5} \mathrm{GlCNAc}_{2}$ at N160 site and SCT-GlcNAc 2 at N173 site, exhibited a subnanomolar level binding affinity $\left(\mathrm{EC}_{50}=\sim 0.20 \mathrm{nM}\right)$. Although the loading level for conjugate 19 (loading $n=155$ ) is lower than that for conjugate 18 (loading $n=265$ ), a 62 -fold enhancement in binding affinity for PG9 was observed. Of note, the binding affinity of conjugate 19 for PG9 was significantly higher than that of gp $120_{\mathrm{M} \cdot \mathrm{CON}-\mathrm{S}}$ $\left(\mathrm{EC}_{50}=\sim 1.12 \mathrm{nM}\right)$ and gp120 $\mathrm{AE} \cdot \mathrm{A} 244(\sim 1.29 \mathrm{nM})$ monomer, suggesting that the multivalent display provides enhanced binding, when compared to monomeric gp120. The conjugate 
20 bearing $\mathrm{Man}_{5} \mathrm{GlNNAc}_{2}$ glycan at both N160 and N173 positions with glycopeptide loading of 150 showed an $\mathrm{EC}_{50}$ of $\sim 12.0 \mathrm{nM}$.

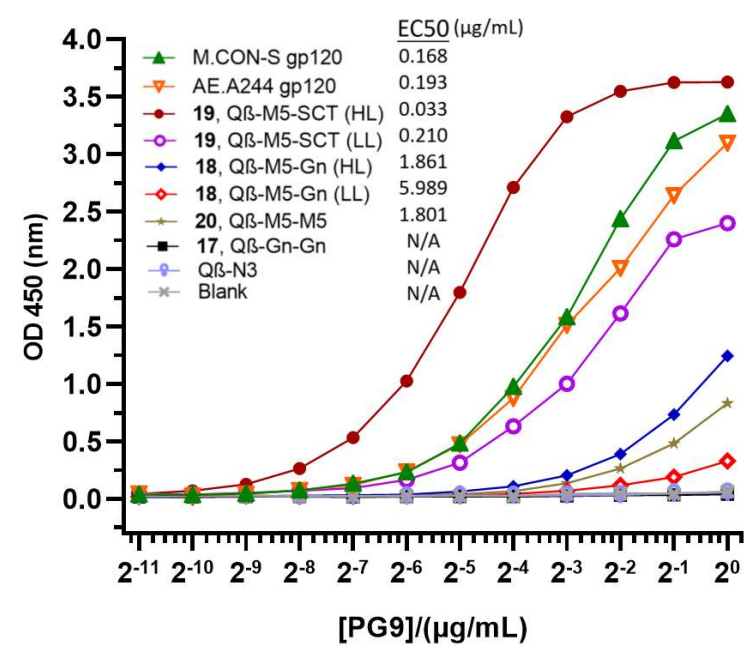

Figure 3. Conventional ELISA binding of V1V2 antigens to bNAb PG9. Q $\beta$-V1V2 conjugates or gp120 were coated on the microtiter plates. PG9 was titrated with two-fold serial dilutions starting from $1 \mu \mathrm{g} / \mathrm{mL}$. LL = low-loading (below 1 peptide/subunit); HL = high-loading (1-2 peptides/subunit); Blank is PBS buffer. Two independent ELISA assays were performed and the results were consistent. The figure shows a representative set of the data.

To compare the effects of glycopeptide antigen loading on the affinity, we also synthesized a panel of $Q \beta$ conjugates with relatively low loading by reducing the amounts of alkyne-tagged glycopeptides (1-2 eq were used) and shortening the incubation time (3-12 h). Thus, conjugate 18 bearing 108 copies of glycopeptide 8 and conjugate 19 bearing 33 copies of glycopeptide 10 (Figure $2 b, d$, respectively) was prepared. The low-loading glycopeptide- $\mathrm{Q} \beta$ conjugate 18 exhibited $\sim 3.2$-fold reduced binding affinity $\left(\mathrm{EC}_{50} \approx 39.9 \mathrm{nM}\right.$, Figure $3, \mathrm{Q} \beta-\mathrm{M} 5-\mathrm{Gn}, \mathrm{LL}$ ) for PG9 compared to the high-loading conjugate (Figure 3, Q $\beta$-M5-Gn, HL). Similarly, low-loading glycopeptide-Q $\beta$ conjugate 19 exhibited $\sim 7.0$-fold reduced binding affinity $\left(\mathrm{EC}_{50} \approx 1.4 \mathrm{nM}\right.$, Figure $3, \mathrm{Q} \beta$-M5-SCT, LL) for PG9 compared to the high-loading conjugate (Figure 3, Q $\beta$-M5-SCT, HL). These data suggest that an appropriate dense presentation of the glycopeptide epitope on the $Q \beta$ nanoparticles are important to achieve the high-affinity binding to the broadly neutralizing antibody PG9. Future studies will be directed to immunization to evaluate the immunogenicity of the glycoconjugates.

\section{Materials and Methods}

\subsection{General Procedures}

Analytical reverse-phase HPLC was performed on a Waters Alliance ${ }^{\circledR}$ e2695 HPLC system equipped with a dual absorbance $2489 \mathrm{UV} /$ Vis detector. Separations were performed using a C18 column (YMC-Triart C18, $4.6 \times 250 \mathrm{~mm}, 5 \mu \mathrm{m}$ ) at a flow rate of $1 \mathrm{~mL} / \mathrm{min}$ using a linear gradient of $5-40 \% \mathrm{MeCN}$ containing $0.1 \%$ FA over $30 \mathrm{~min}$. ESI-MS spectra were obtained using a Waters SQ Detector 2 single quadrupole mass spectrometer. MALDI-TOF analysis was performed using a Bruker UltrafleXtreme (UTX) mass spectrometer with TOF/TOF detection. Preparative RP-HPLC was performed on a Waters 600 HPLC system equipped with a dual absorbance UV detector using a C18 column (Waters-Symmetry Prep $\mathrm{C} 18,19 \times 300 \mathrm{~mm}, 7 \mu \mathrm{m}$ ) at a flow-rate of $10 \mathrm{~mL} / \mathrm{min}$, or a C18 column (Waters XBridge, Prep Shield, $10 \times 250 \mathrm{~mm}, 5 \mu \mathrm{m}$ ) at a flow-rate of $4 \mathrm{~mL} / \mathrm{min}$. The column was eluted using a linear gradient of $10-30 \% \mathrm{MeCN}$ containing $0.1 \%$ FA over $30 \mathrm{~min}$. 


\subsection{Peptide Synthesis}

Peptide synthesis was performed under microwave synthesis conditions using a CEM Liberty Blue microwave peptide synthesizer. Synthesis was based on Fmoc chemistry using Rink Amide resin $(0.66 \mathrm{mmol} / \mathrm{g})$ on a $0.1 \mathrm{mmol}$ scale. Couplings were performed using 5 equiv of Fmoc-protected amino acids (or 3 equiv of glycosylamino acids), 5 equiv of DIC and 5 equiv of HOBt in DMF. Double couplings were performed at $45^{\circ} \mathrm{C}$ for $20 \mathrm{~min}$ $(2 \times)$ for Fmoc-Cys(Trt)-OH, Fmoc-His(Trt)-OH and Fmoc-Arg(Pbf)-OH. The selectively protected glycosylamino acid building block Fmoc-Asn( $\left.\mathrm{Ac}_{3} \mathrm{GlcNAc}\right)-\mathrm{OH}$ (1) and FmocAsn(DEIPS ${ }_{3}$ GlcNAc)-OH (2) was introduced at predetermined sites and the coupling was performed at $45{ }^{\circ} \mathrm{C}$ for $40 \mathrm{~min}$. All other amino acids were coupled at $90{ }^{\circ} \mathrm{C}$ for $2 \mathrm{~min}$. Fmoc deblocking was performed in $20 \%$ piperidine in DMF containing $0.1 \mathrm{M} \mathrm{HOBt}$. The Nterminus was capped with an alkyne tag by treatment with 4-pentynoic acid following the same method as introduction of glycosylamino acid. After synthesis, the resin was washed with DMF $(3 \times)$ and DCM $(3 \times)$, dried. Resin cleavage and global peptide deprotection were achieved using freshly prepared cocktail $\mathrm{R}$ (TFA/Thioanisole/Ethanedithiol/Anisole [90/5/3/2]) and shaking for $2 \mathrm{~h}$. The peptide was separated from the resin by filtration and the peptide was precipitated onto cold $\left(-20^{\circ} \mathrm{C}\right)$ diethyl ether. The precipitated crude GlcNAc-peptide 3 was not further purified and was used directly for the synthesis of GlcNAc-peptide 4 and 5.

\subsubsection{Synthesis of GlcNAc-Peptide 4 Bearing a GlcNAc at Asn160 and a $\mathrm{Ac}_{3} \mathrm{GlcNAc}$} at Asn173

A solution of the crude GlcNAc-peptide $3(0.02 \mathrm{mmol})$ in water $(45 \mathrm{~mL}$, final concentration: $1-2 \mathrm{mg} / \mathrm{mL})$ was added DMSO $(5 \mathrm{~mL})$. The mixture was shaken at $\mathrm{rt}$ for $24 \mathrm{~h}$ to cyclize the peptide. The crude peptides were purified by RP-HPLC, yielding the target glycopeptide 4 as a white powder ( $37.7 \mathrm{mg}, 56 \%$ overall yield from SPPS). Analytical RP-HPLC, $t_{\mathrm{R}}=16.57 \mathrm{~min}$. ESI-MS: calcd., $\mathrm{M}=3367.7$; found, $842.7[\mathrm{M}+4 \mathrm{H}]^{4+}, 1123.51$ $[\mathrm{M}+3 \mathrm{H}]^{3+}, 1684.47[\mathrm{M}+2 \mathrm{H}]^{2+}$. Deconvolution mass, 3367.5.

\subsubsection{Synthesis of GlcNAc-Peptide 5 Bearing a GlcNAc at Asn 160 and a GlcNAc at Asn173}

A solution of the crude GlcNAc-peptide $3(0.02 \mathrm{mmol})$ in $2.5 \%$ aq. hydrazine (final concentration: $1-2 \mathrm{mg} / \mathrm{mL}$ ) was shaken at $\mathrm{rt}$ for $3 \mathrm{~h}$ to cyclize the peptide and to remove the acetyl protecting group simultaneously. The crude peptides were purified by RP-HPLC, yielding the target GlcNAc-peptide 5 [48] as a white powder $(39.5 \mathrm{mg}, 61 \%$ overall yield from SPPS). Analytical RP-HPLC, $t_{\mathrm{R}}=14.57 \mathrm{~min}$. ESI-MS: calcd., $\mathrm{M}=3241.6$; found, $649.04[\mathrm{M}+5 \mathrm{H}]^{5+}, 811.22[\mathrm{M}+4 \mathrm{H}]^{++}, 1081.68[\mathrm{M}+3 \mathrm{H}]^{3+}, 1621.72[\mathrm{M}+2 \mathrm{H}]^{2+}$ Deconvolution mass, 3241.4 .

\subsection{EndoM Mutant-Catalyzed Transglycosylation}

3.3.1. Synthesis of Glycopeptide 8 Bearing a Man ${ }_{5} \mathrm{GlcNAc}_{2}$ Glycan at Asn160 and a GlcNAc at Asn173

EndoM-N175Q mediated transglycosylation of Man ${ }_{5}$ GlcNAc oxazoline 6 to GlcNAcpeptide was performed following a similar procedure as we have previously reported [44]. A solution of glycopeptide $4(6.0 \mathrm{mg}, 1.8 \mu \mathrm{mol})$ and Man ${ }_{5} \mathrm{GlcNAc}$ oxazoline 6 (14.5 mg, $14.3 \mu \mathrm{mol}, 8 \mathrm{eq})$ in a phosphate buffer $(100 \mathrm{mM}, \mathrm{pH} 7.2,0.3 \mathrm{~mL})$ was incubated with EndoM mutant N175Q (final concentration, $0.1 \mathrm{mg} / \mathrm{mL}$ ) at $30{ }^{\circ} \mathrm{C}$. The reaction was monitored by RP-HPLC-MS. After $2 \mathrm{~h}$, the reaction was quenched with $0.1 \%$ aq. TFA. The mixture was centrifuged and filtered through a $0.45 \mu \mathrm{m}$ syringe filter. The filtrate was purified by RP-HPLC to give glycopeptide 7 . The lyophilized glycopeptide 7 was dissolved in $2 \%$ aq. hydrazine $(1 \mathrm{~mL})$ and the solution was shaken for $1 \mathrm{~h}$ for deacetylation. The mixture was centrifuged and filtered through a $0.45 \mu \mathrm{m}$ syringe filter. The filtrate was purified by RP-HPLC, yielding the target glycopeptide 8 as a white powder $(5.5 \mathrm{mg}, 68 \%)$. Analytical RP-HPLC, $t_{\mathrm{R}}=14.18 \mathrm{~min}$. ESI-MS: calcd., $\mathrm{M}=4255.5$; found, $851.94[\mathrm{M}+5 \mathrm{H}]^{5+}, 1064.63$ $[\mathrm{M}+4 \mathrm{H}]^{4+}, 1419.32[\mathrm{M}+3 \mathrm{H}]^{3+}$. Deconvolution mass, 4254.7 . 
3.3.2. Synthesis of Glycopeptide 10 Bearing a Man ${ }_{5} \mathrm{GlNAc}_{2}$ Glycan at Asn160 and a Sialylated Complex-Type Glycan (SCT) at Asn173

EndoM-N175Q mediated transglycosylation of complex-type N-glycan oxazoline to GlcNAc-peptide was performed following a similar procedure as we previously reported [44,49,50]. A solution of glycopeptide $8(3.0 \mathrm{mg}, 0.70 \mu \mathrm{mol})$ and SCT-oxazoline 9 [44] (11.3 mg, $5.6 \mu \mathrm{mol}, 4 \mathrm{eq})$ in a phosphate buffer $(100 \mathrm{mM}, \mathrm{pH} 7.2,0.15 \mathrm{~mL})$ was incubated with EndoM mutant N175Q (final concentration, $0.1 \mathrm{mg} / \mathrm{mL}$ ) at $30^{\circ} \mathrm{C}$. The reaction was monitored by RP-HPLC-MS. After $1 \mathrm{~h}$, the reaction was quenched with $0.1 \%$ aq. TFA. The mixture was centrifuged and filtered through a $0.45 \mu \mathrm{m}$ syringe filter. The filtrate was purified by RP-HPLC, yielding the target glycopeptide $\mathbf{1 0}$ as a white powder $(4.4 \mathrm{mg}, 86 \%)$. Analytical RP-HPLC, $t_{\mathrm{R}}=15.10 \mathrm{~min}$. ESI-MS: calcd., $\mathrm{M}=6258.3$; found, $1043.91[\mathrm{M}+6 \mathrm{H}]^{6+}$, $1252.44[\mathrm{M}+5 \mathrm{H}]^{5+}, 1465.48[\mathrm{M}+4 \mathrm{H}]^{4+}$. Deconvolution mass, 6257.2.

3.3.3. Synthesis of Glycopeptide 11 Bearing a Man ${ }_{5} \mathrm{GlNAc}_{2}$ Glycan at Asn160 and a $\mathrm{Man}_{5} \mathrm{GlcNAc}_{2}$ Glycan at Asn173

A solution of glycopeptide 5 (5.0 mg, $1.5 \mu \mathrm{mol})$ and $\mathrm{Man}_{5} \mathrm{GlcNAc}$ oxazoline 6 (12.5 mg, $12.3 \mu \mathrm{mol}, 8 \mathrm{eq})$ in a phosphate buffer $(100 \mathrm{mM}, \mathrm{pH} 7.2,0.25 \mathrm{~mL})$ was incubated with EndoM mutant N175Q (final concentration, $0.1 \mathrm{mg} / \mathrm{mL}$ ) at $30^{\circ} \mathrm{C}$. The reaction was monitored by RP-HPLC-MS. After $2 \mathrm{~h}$, the reaction was quenched with $0.1 \%$ aq. TFA. The mixture was centrifuged and filtered through a $0.45 \mu \mathrm{m}$ syringe filter. The filtrate was purified by RPHPLC, yielding the target glycopeptide 11 as a white powder $(5.5 \mathrm{mg}, 68 \%)$. Alternatively, glycopeptide 11 ( $3.5 \mathrm{mg}, 71 \%$ ) was also obtained by transferring Man ${ }_{5}$ GlcNAc oxazoline 6 ( $3.8 \mathrm{mg}, 3.8 \mu \mathrm{mol}, 4 \mathrm{eq}$ ) to glycopeptide $5(4.0 \mathrm{mg}, 0.94 \mu \mathrm{mol}$ ) following the above condition. Analytical RP-HPLC, $t_{\mathrm{R}}=13.67 \mathrm{~min}$. ESI-MS: calcd., $\mathrm{M}=5269.4$; found, $1054.97[\mathrm{M}+5 \mathrm{H}]^{5+}$, $1318.25[\mathrm{M}+4 \mathrm{H}]^{4+}, 1757.36[\mathrm{M}+3 \mathrm{H}]^{3+}$. Deconvolution mass, 5269.0.

\subsection{Expression and Functionalization of Bacteriophage $Q \beta$ Particles}

\subsubsection{Expression of Wild Type Bacteriophage $\mathrm{Q} \beta$}

The virus-like nanoparticle $Q \beta$ was expressed as previously described [51]. The BL21(DE3) E. coli strain was transformed with the plasmid encoding the $Q \beta$ subunit. The clones were picked and verified. The expression of the $Q \beta$ was induced with IPTG and performed at $25{ }^{\circ} \mathrm{C}$. The bacteria cells were harvested and resuspended into PBS buffer ( $\mathrm{pH}$ 7.4) and then lysed by ultrasonication (Branson digital sonifier). The $\mathrm{Q} \beta$ VLP was purified from the cell lysate through a Sepharose CL-4B (GE Healthcare Life Sciences) size exclusion column. Fractions were confirmed and characterized by MALDI-TOF MS and electrophoresis analysis. The protein was quantified by NanoDrop at $280 \mathrm{~nm}$ with an E\% of 26.3 .

\subsubsection{Functionalization of $\mathrm{WT} Q \beta$}

WT $\mathrm{Q} \beta$ (12, $45 \mathrm{mg})$ in PBS buffer $(150 \mathrm{mM}, \mathrm{pH} 7.4$, final protein concentration: $4 \mathrm{mg} / \mathrm{mL}$ ) was incubated with NHS-activated compound 13 (12 equivalents) at $37^{\circ} \mathrm{C}$ for $3 \mathrm{~h}$. The progress of the functionalization of WT $Q \beta$ was monitored by MALDI-TOF analysis. The reaction mixture was transferred into a dialysis bag (MWCO $10 \mathrm{KDa})$, and the solution was dialyzed against deionized water $(2 \mathrm{~L} \times 3)$. The product could be concentrated by centrifugal filtration using Millipore $10 \mathrm{KDa}$ MWCO filters if needed. The product was quantified by NanoDrop at $280 \mathrm{~nm}$ with an $\mathrm{E} \%$ of 26.3. Average loading of surface azido groups was estimated by MALDI-TOF analysis.

\subsection{Conjugation of V1V2 Glycopeptides to $Q \beta$ through $C u A A C$}

\subsubsection{General Reaction Conditions for CuAAC}

Synthesis of glycopeptide- $\mathrm{Q} \beta$ conjugates (17-20) was achieved using the CuAAC click reaction, with conditions similar to those previously reported [52]. All solvents were degassed before use. In general, the following reagents were combined in the following order, $2 \mathrm{mg} 14$ ( $3 \mathrm{mg} / \mathrm{mL}$ stock in water), $1 \mathrm{M}$ phosphate buffer ( $\mathrm{pH} 7.4$, final $80 \mathrm{mM}$ ), 
alkyne-tagged glycopeptides $(5,8, \mathbf{1 0}, \mathbf{1 1})$ [2-3 eq./subunit], 50\% aq. sucrose (final 10\%), pre-mixed $\mathrm{Cu}$-THPTA solution $\left(\mathrm{CuSO}_{4}, 500 \mathrm{mM}\right.$ in water [4 eq.] + THPTA ligand 15, $1 \mathrm{M}$ in water, [20 eq.]), aminoguanidine (1 $\mathrm{M}$ in water, 100 eq. compared to 14), and sodium ascorbate (1 $\mathrm{M}$ in water, $100 \mathrm{eq}$. compared to 14). After the addition of sodium ascorbate, the reaction tube was flushed with argon and sealed. The mixture was shaken at $37^{\circ} \mathrm{C}$ overnight. The low-loading glycopeptide- $\mathrm{Q} \beta$ conjugates were synthesized by a similar method, however, $0.5-1$ eq. / subunit of $\mathbf{8}$ or $\mathbf{1 0}$ was added to achieve low-loading. The remaining unreacted azido groups on $Q \beta$ virion were capped in a second CuAAC reaction using a large excess (100 eq. compared to 14) of 4-pentyn-1-ol (16) for a further $3 \mathrm{~h}$. Purification of the glycopeptide-Q $\beta$ conjugates was performed by dialysis against PBS buffer (50 mM, pH 7.4) using a dialysis bag (MWCO $300 \mathrm{KDa}$, BIOTECH CE TRIAL ${ }^{\circledR}$, Repligen, Waltham, MA, USA). The product was quantified by NanoDrop at $280 \mathrm{~nm}$ with an E\% of 26.3. Average loading of surface glycopeptides was estimated by reducing SDS-PAGE analysis.

\subsubsection{SDS-PAGE Sample Preparation and Analysis}

Approximately $3 \mu \mathrm{g}$ of the dialyzed glycopeptide- $\mathrm{Q} \beta$ conjugate or the conjugation reaction mixture diluted in water was mixed with $5 \mu \mathrm{L}$ of $2 X$ SDS loading dye containing $\beta$-mercaptoethanol to make a final volume of $10 \mu \mathrm{L}$. The samples were denatured at $95{ }^{\circ} \mathrm{C}$ for $5 \mathrm{~min}$ and cooled to $4{ }^{\circ} \mathrm{C}$ before loading. Precast polyacrylamide stain-free gels 4-15\% were used for electrophoresis (Mini-PROTEANTM TGX Stain-Free ${ }^{\mathrm{TM}}$ Protein Gels, Bio-Rad, Hercules, CA, USA, Cat. \# 4568086). $6 \mu \mathrm{L}$ of protein ladder (Precision Plus Protein Standards, Bio-Rad, Hercules, CA, USA, Cat. \# 1610363) was loaded for reference. The gels were run in 1X Tris/Glycine/SDS buffer at $220 \mathrm{~V}$ for 35 min and stained with Coomassie Brilliant Blue R-250 Staining (Amresco, Solon, OH, USA), then destain the gel with destaining solution (40\% methanol and 10\% glacial acetic acid). Gel imaging was done using Gel Doc ${ }^{\mathrm{TM}}$ EZ Imager (Bio-Rad, Hercules, CA, USA).

\subsubsection{MALDI-TOF MS Sample Preparation and Analysis}

The V1V2-derivitized $\mathrm{Q} \beta$ antigens (2 $\mu \mathrm{g}$ ) were mixed with dithiothreitol (DTT) (final concentration $0.1 \mathrm{M}$ ). The mixture was incubated at $37^{\circ} \mathrm{C}$ for $1 \mathrm{~h}$. The resulting samples $(1 \mu \mathrm{L})$ were mixed 1:1 with sinapic acid (SA) solution (50:50 water/acetonitrile with $0.1 \%$ TFA) onto the MALDI plate and allow to air dry. A second SA $(1 \mu \mathrm{L})$ matrix was added on the top of the dried sample and allow to air dry.

\subsection{ELISA Analysis of the Binding between PG9 and Glycopeptide-Q $\beta$ Conjugate}

The high-binding Ultra Cruz 96-well plates (Santa Cruz Biotech, Dallas, TX, USA) were firstly coated with $100 \mathrm{ng}$ of the $\mathrm{Q} \beta$ antigen or gp120 in $100 \mu \mathrm{L}$ of PBS buffer at $4{ }^{\circ} \mathrm{C}$ overnight. Afterwards, the plates were washed with PBS/0.05\% Tween-20 (PBS-T) three times and then saturated with $2 \%(w / v \%)$ sodium casein under incubation at $37{ }^{\circ} \mathrm{C}$ for $1 \mathrm{~h}$. The plates were again washed with PBS-T for three times. Next, the PG9 bNAb with various concentrations $(1 \mu \mathrm{g} / \mathrm{mL}$ to $0.5 \mathrm{ng} / \mathrm{mL}$ with a serial of two-fold dilutions) was applied to the assay plate. The binding of the bNAb was proceeded at room temperature for $1 \mathrm{~h}$ and then washed by the PBS-T solution four times. Subsequently, $100 \mu \mathrm{L}$ of the 1:10,000 diluted HRP-labeled goat anti-human IgG antibody (KPL) was applied to the well plate. The binding occurred at room temperature for $30 \mathrm{~min}$, followed by extensive washes with PBS-T solution five times. Finally, $100 \mu \mathrm{L}$ the TMB 2-component microwell peroxidase substrates (SeraCare, Milford, MA, USA) was added to each well. The color was developed in dark at room temperature for $30 \mathrm{~min}$, and then quenched with $100 \mu \mathrm{L}$ of the $1 \mathrm{M} \mathrm{H}_{3} \mathrm{PO}_{4}$ solution. Final results were read by subtracting the optical density (OD) at $450 \mathrm{~nm}$ by the $\mathrm{OD}$ at $550 \mathrm{~nm}$. 


\section{Conclusions}

An efficient chemoenzymatic synthesis of HIV-1 glycopeptide- $\mathrm{Q} \beta$ conjugates is described. The ratio of glycopeptide epitope loading on the $Q \beta$ bacteriophage can be modulated by adjusting the ratios of tag introduction into $Q \beta$ followed by a click reaction. The conjugates demonstrate much enhanced affinity for neutralizing antibody PG9 over monomeric envelope glycoprotein gp120. This study suggests that an appropriate multivalent display of the structurally well-defined glycopeptide epitope might catch the tertiary conformational epitopes of PG9. Thus, the synthetic HIV-1 glycopeptide- $Q \beta$ conjugates represent a valuable HIV-1 vaccine candidate, the immunogenicity of which should be evaluated in animal models.

Supplementary Materials: The following are available online at https://www.mdpi.com/article/10 .3390/ijms222212538/s1.

Author Contributions: G.Z., C.T. and L.-X.W. conceived the concept and designed the experiments. G.Z. and C.T. performed peptide synthesis, transglycosylation, $Q \beta$ functionalization and conjugation experiments. Q.Y. and R.Z. expressed the wild type bacteriophage Q $\beta$. R.Z. and G.Z. performed ELISA and analyzed the data. L.-X.W. supervised the research; G.Z., C.T. and L.-X.W. wrote and edited the manuscript. All authors have read and agreed to the published version of the manuscript.

Funding: This work was supported by the National Institutes of Health (NIH Grants R01AI113896, to L.-X.W).

Acknowledgments: We thank members of the Wang lab for technical assistance and helpful discussions. PG9 and monomeric gp120 $\mathrm{MCON} \cdot \mathrm{S}, \mathrm{gp} 120_{\mathrm{AE}} \cdot \mathrm{A} 244$ were both obtained from the National Institutes of Health (NIH) through the AIDS Reagent Program.

Conflicts of Interest: The authors declare no conflict of interest.

\section{References}

1. Nabel, G.J. Challenges and opportunities for development of an AIDS vaccine. Nat. Cell Biol. 2001, 410, 1002-1007. [CrossRef] [PubMed]

2. Zolla-Pazner, S. Identifying epitopes of HIV-1 that induce protective antibodies. Nat. Rev. Immunol. 2004, 4, 199-210. [CrossRef]

3. Rerks-Ngarm, S.; Pitisuttithum, P.; Nitayaphan, S.; Kaewkungwal, J.; Chiu, J.; Paris, R.; Premsri, N.; Namwat, C.; De Souza, M.; Adams, E.; et al. Vaccination with ALVAC and AIDSVAX to Prevent HIV-1 Infection in Thailand. N. Engl. J. Med. 2009, 361, 2209-2220. [CrossRef] [PubMed]

4. Walker, L.M.; Burton, D.R. Rational antibody-based HIV-1 vaccine design: Current approaches and future directions. Curr. Opin. Immunol. 2010, 22, 358-366. [CrossRef]

5. Virgin, H.W.; Walker, B.D. Immunology and the elusive AIDS vaccine. Nat. Cell Biol. 2010, 464, 224-231. [CrossRef]

6. Kim, J.H.; Rerks-Ngarm, S.; Excler, J.-L.; Michael, N.L. HIV vaccines: Lessons learned and the way forward. Curr. Opin. HIV AIDS 2010, 5, 428-434. [CrossRef]

7. Burton, D.R.; Ahmed, R.; Barouch, D.H.; Butera, S.T.; Crotty, S.; Godzik, A.; Kaufmann, D.E.; McElrath, M.J.; Nussenzweig, M.C.; Pulendran, B.; et al. A Blueprint for HIV Vaccine Discovery. Cell Host Microbe 2012, 12, 396-407. [CrossRef]

8. Kwong, P.D.; Mascola, J.R.; Nabel, G.J. Broadly neutralizing antibodies and the search for an HIV-1 vaccine: The end of the beginning. Nat. Rev. Immunol. 2013, 13, 693-701. [CrossRef] [PubMed]

9. Sok, D.; Le, K.M.; Vadnais, M.; Saye-Francisco, K.L.; Jardine, J.G.; Torres, J.L.; Berndsen, Z.T.; Kong, L.; Stanfield, R.; Ruiz, J.; et al. Rapid elicitation of broadly neutralizing antibodies to HIV by immunization in cows. Nat. Cell Biol. 2017, 548, 108-111. [CrossRef]

10. Lee, J.H.; Crotty, S. HIV vaccinology: 2021 update. Semin. Immunol. 2021, 51, 101470. [CrossRef]

11. Kwong, P.D.; Mascola, J.R.; Nabel, G.J. The changing face of HIV vaccine research. J. Int. AIDS Soc. 2012, 15, 17407. [CrossRef]

12. Wei, X.; Decker, J.M.; Wang, S.; Hui, H.; Kappes, J.C.; Wu, X.; Salazar-Gonzalez, J.F.; Salazar, M.G.; Kilby, J.M.; Saag, M.S.; et al. Antibody neutralization and escape by HIV. Nature 2003, 422, 307-312. [CrossRef]

13. Trkola, A.; Purtscher, M.; Muster, T.; Ballaun, C.; Buchacher, A.; Sullivan, N.; Srinivasan, K.; Sodroski, J.; Moore, J.P.; Katinger, H. Human monoclonal antibody 2G12 defines a distinctive neutralization epitope on the gp120 glycoprotein of human immunodeficiency virus type. J. Virol. 1996, 70, 1100-1108. [CrossRef] [PubMed]

14. Sanders, R.W.; Venturi, M.; Schiffner, L.; Kalyanaraman, R.; Katinger, H.; Lloyd, K.O.; Kwong, P.D.; Moore, J.P. The MannoseDependent Epitope for Neutralizing Antibody 2G12 on Human Immunodeficiency Virus Type 1 Glycoprotein gp. J. Virol. 2002, 76, 7293-7305. [CrossRef] [PubMed]

15. Scanlan, C.N.; Pantophlet, R.; Wormald, M.; Saphire, E.O.; Stanfield, R.; Wilson, I.A.; Katinger, H.; Dwek, R.A.; Rudd, P.M.; Burton, D.R. The Broadly Neutralizing Anti-Human Immunodeficiency Virus Type 1 Antibody 2G12 Recognizes a Cluster of $\alpha 1 \rightarrow 2$ Mannose Residues on the Outer Face of gp. J. Virol. 2002, 76, 7306-7321. [CrossRef] 
16. Calarese, D.A.; Scanlan, C.N.; Zwick, M.B.; Deechongkit, S.; Mimura, Y.; Kunert, R.; Zhu, P.; Wormald, M.R.; Stanfield, R.L.; Roux, K.H.; et al. Antibody Domain Exchange Is an Immunological Solution to Carbohydrate Cluster Recognition. Science 2003, 300, 2065-2071. [CrossRef]

17. Calarese, D.A.; Lee, H.-K.; Huang, C.-Y.; Best, M.D.; Astronomo, R.D.; Stanfield, R.L.; Katinger, H.; Burton, D.R.; Wong, C.-H.; Wilson, I.A. Dissection of the carbohydrate specificity of the broadly neutralizing anti-HIV-1 antibody 2G. Proc. Natl. Acad. Sci. USA 2005, 102, 13372-13377. [CrossRef]

18. Walker, L.M.; Phogat, S.K.; Chan-Hui, P.-Y.; Wagner, D.; Phung, P.; Goss, J.L.; Wrin, T.; Simek, M.D.; Fling, S.; Mitcham, J.L.; et al. Broad and Potent Neutralizing Antibodies from an African Donor Reveal a New HIV-1 Vaccine Target. Science 2009, 326, 285-289. [CrossRef]

19. Walker, L.M.; Simek, M.D.; Priddy, F.; Gach, J.S.; Wagner, D.; Zwick, M.B.; Phogat, S.K.; Poignard, P.; Burton, D.R. A Limited Number of Antibody Specificities Mediate Broad and Potent Serum Neutralization in Selected HIV-1 Infected Individuals. PLoS Pathog. 2010, 6, e1001028. [CrossRef] [PubMed]

20. Doores, K.; Burton, D.R. Variable Loop Glycan Dependency of the Broad and Potent HIV-1-Neutralizing Antibodies PG9 and PG. J. Virol. 2010, 84, 10510-10521. [CrossRef]

21. Bonsignori, M.; Hwang, K.K.; Chen, X.; Tsao, C.Y.; Morris, L.; Gray, E.; Marshall, D.J.; Crump, J.A.; Kapiga, S.H.; Sam, N.E.; et al. Analysis of a clonal lineage of HIV-1 envelope V2/V3 conformational epitope-specific broadly neutralizing antibodies and their inferred unmutated common ancestors. J. Virol. 2011, 85, 9998-10009. [CrossRef]

22. Walker, L.M.; Huber, M.; Doores, K.; Falkowska, E.; Pejchal, R.; Julien, J.-P.; Wang, S.-K.; Ramos, A.; Chan-Hui, P.-Y.; Moyle, M.; et al. Broad neutralization coverage of HIV by multiple highly potent antibodies. Nat. Cell Biol. 2011, 477, 466-470. [CrossRef]

23. Pejchal, R.; Doores, K.J.; Walker, L.M.; Khayat, R.; Huang, P.-S.; Wang, S.-K.; Stanfield, R.L.; Julien, J.-P.; Ramos, A.; Crispin, M.; et al. A Potent and Broad Neutralizing Antibody Recognizes and Penetrates the HIV Glycan Shield. Science 2011, 334, 1097-1103. [CrossRef] [PubMed]

24. McLellan, J.S.; Pancera, M.; Carrico, C.; Gorman, J.; Julien, J.P.; Khayat, R.; Louder, R.; Pejchal, R.; Sastry, M.; Dai, K.; et al. Structure of HIV-1 gp120 V1/V2 domain with broadly neutralizing antibody. PGNature 2011, 480, 336-343. [CrossRef] [PubMed]

25. Amin, M.N.; McLellan, J.; Huang, W.; Orwenyo, J.; Burton, D.R.; Koff, W.C.; Kwong, P.D.; Wang, L.-X. Synthetic glycopeptides reveal the glycan specificity of HIV-neutralizing antibodies. Nat. Chem. Biol. 2013, 9, 521-526. [CrossRef]

26. Orwenyo, J.; Cai, H.; Giddens, J.; Amin, M.N.; Toonstra, C.; Wang, L.-X. Systematic Synthesis and Binding Study of HIV V3 Glycopeptides Reveal the Fine Epitopes of Several Broadly Neutralizing Antibodies. ACS Chem. Biol. 2017, 12, 1566-1575. [CrossRef] [PubMed]

27. Cai, H.; Orwenyo, J.; Giddens, J.; Yang, Q.; Zhang, R.; LaBranche, C.C.; Montefiori, D.C.; Wang, L.-X. Synthetic Three-Component HIV-1 V3 Glycopeptide Immunogens Induce Glycan-Dependent Antibody Responses. Cell Chem. Biol. 2017, 24, 1513-1522.e4. [CrossRef] [PubMed]

28. Cai, H.; Orwenyo, J.; Guenaga, J.; Giddens, J.; Toonstra, C.; Wyatt, R.T.; Wang, L.-X. Synthetic multivalent V3 glycopeptides display enhanced recognition by glycan-dependent HIV-1 broadly neutralizing antibodies. Chem. Commun. 2017, 53, 5453-5456. [CrossRef]

29. Cai, H.; Zhang, R.; Orwenyo, J.; Giddens, J.; Yang, Q.; Labranche, C.C.; Montefiori, D.C.; Wang, L.-X. Multivalent Antigen Presentation Enhances the Immunogenicity of a Synthetic Three-Component HIV-1 V3 Glycopeptide Vaccine. ACS Central Sci. 2018, 4, 582-589. [CrossRef]

30. Cai, H.; Zhang, R.-S.; Orwenyo, J.; Giddens, J.P.; Yang, Q.; LaBranche, C.C.; Montefiori, D.C.; Wang, L.-X. Synthetic HIV V3 Glycopeptide Immunogen Carrying a N334 N-Glycan Induces Glycan-Dependent Antibodies with Promiscuous Site Recognition. J. Med. Chem. 2018, 61, 10116-10125. [CrossRef]

31. Alam, S.M.; Aussedat, B.; Vohra, Y.; Meyerhoff, R.R.; Cale, E.M.; Walkowicz, W.E.; Radakovich, N.A.; Anasti, K.; Armand, L.; Parks, R.; et al. Mimicry of an HIV broadly neutralizing antibody epitope with a synthetic glycopeptide. Sci. Transl. Med. 2017, 9, eaai7521. [CrossRef] [PubMed]

32. Bonsignori, M.; Kreider, E.F.; Fera, D.; Meyerhoff, R.R.; Bradley, T.; Wiehe, K.; Alam, S.M.; Aussedat, B.; Walkowicz, W.E.; Hwang, K.-K.; et al. Staged induction of HIV-1 glycan-dependent broadly neutralizing antibodies. Sci. Transl. Med. 2017, 9, eaai7514. [CrossRef] [PubMed]

33. Bachmann, M.F.; Jennings, G.T. Vaccine delivery: A matter of size, geometry, kinetics and molecular patterns. Nat. Rev. Immunol. 2010, 10, 787-796. [CrossRef] [PubMed]

34. Roldao, A.; Mellado, M.C.M.; Castilho, L.R.; Carrondo, M.; Alves, P. Virus-like particles in vaccine development. Expert Rev. Vaccines 2010, 9, 1149-1176. [CrossRef]

35. Jardine, J.; Julien, J.-P.; Menis, S.; Ota, T.; Kalyuzhniy, O.; McGuire, A.; Sok, D.; Huang, P.-S.; MacPherson, S.; Jones, M.; et al. Rational HIV Immunogen Design to Target Specific Germline B Cell Receptors. Science 2013, 340, 711-716. [CrossRef]

36. McGuire, A.; Hoot, S.; Dreyer, A.M.; Lippy, A.; Stuart, A.; Cohen, K.W.; Jardine, J.; Menis, S.; Scheid, J.F.; West, A.P.; et al. Engineering HIV envelope protein to activate germline B cell receptors of broadly neutralizing anti-CD4 binding site antibodies. J. Exp. Med. 2013, 210, 655-663. [CrossRef] [PubMed]

37. Haynes, B.F.; Kelsoe, G.; Harrison, S.C.; Kepler, T. B-cell-lineage immunogen design in vaccine development with HIV-1 as a case study. Nat. Biotechnol. 2012, 30, 423-433. [CrossRef] 
38. Julien, J.-P.; Lee, J.H.; Cupo, A.; Murin, C.D.; Derking, R.; Hoffenberg, S.; Caulfield, M.J.; King, C.R.; Marozsan, A.J.; Klasse, P.J.; et al. Asymmetric recognition of the HIV-1 trimer by broadly neutralizing antibody PG. Proc. Natl. Acad. Sci. USA 2013, 110, 4351-4356. [CrossRef]

39. Wu, X.; Ye, J.; DeLaitsch, A.T.; Rashidijahanabad, Z.; Lang, S.; Kakeshpour, T.; Zhao, Y.; Ramadan, S.; Saavedra, P.V.; YuzbasiyanGurkan, V.; et al. Chemoenzymatic Synthesis of 9NHAc-GD2 Antigen to Overcome the Hydrolytic Instability of O -AcetylatedGD2 for Anticancer Conjugate Vaccine Development. Angew. Chem. Int. Ed. 2021, 60, 24179-24188. [CrossRef]

40. Wu, X.; McKay, C.; Pett, C.; Yu, J.; Schorlemer, M.; Ramadan, S.; Lang, S.; Behren, S.; Westerlind, U.; Finn, M.G.; et al. Synthesis and Immunological Evaluation of Disaccharide Bearing MUC-1 Glycopeptide Conjugates with Virus-like Particles. ACS Chem. Biol. 2019, 14, 2176-2184. [CrossRef] [PubMed]

41. Yin, Z.; Dulaney, S.; McKay, C.; Baniel, C.; Kaczanowska, K.; Ramadan, S.; Finn, M.G.; Huang, X. Chemical Synthesis of GM2 Glycans, Bioconjugation with Bacteriophage Q $\beta$, and the Induction of Anticancer Antibodies. ChemBioChem 2015, 17, 174-180. [CrossRef] [PubMed]

42. Yin, Z.; Chowdhury, S.; McKay, C.; Baniel, C.; Wright, W.S.; Bentley, P.; Kaczanowska, K.; Gildersleeve, J.C.; Finn, M.; BenMohamed, L.; et al. Significant Impact of Immunogen Design on the Diversity of Antibodies Generated by Carbohydrate-Based Anticancer Vaccine. ACS Chem. Biol. 2015, 10, 2364-2372. [CrossRef]

43. Astronomo, R.D.; Kaltgrad, E.; Udit, A.K.; Wang, S.-K.; Doores, K.; Huang, C.-Y.; Pantophlet, R.; Paulson, J.C.; Wong, C.-H.; Finn, M.; et al. Defining Criteria for Oligomannose Immunogens for HIV Using Icosahedral Virus Capsid Scaffolds. Chem. Biol. 2010, 17, 357-370. [CrossRef]

44. Toonstra, C.; Amin, M.N.; Wang, L.-X. Site-Selective Chemoenzymatic Glycosylation of an HIV-1 Polypeptide Antigen with Two Distinct N-Glycans via an Orthogonal Protecting Group Strategy. J. Org. Chem. 2016, 81, 6176-6185. [CrossRef]

45. Umekawa, M.; Huang, W.; Li, B.; Fujita, K.; Ashida, H.; Wang, L.X.; Yamamoto, K. Mutants of Mucor hiemalis endo-beta-Nacetylglucosaminidase show enhanced transglycosylation and glycosynthase-like activities. J. Biol. Chem. 2008, 283, 4469-4479. [CrossRef]

46. Lee, J.C.; Timasheff, S.N. The stabilization of proteins by sucrose. J. Biol. Chem. 1981, 256, 7193-7201. [CrossRef]

47. Aussedat, B.; Vohra, Y.; Park, P.K.; Fernández-Tejada, A.; Alam, S.M.; Dennison, S.M.; Jaeger, F.H.; Anasti, K.; Stewart, S.; Blinn, J.H.; et al. Chemical Synthesis of Highly Congested gp120 V1V2 N-Glycopeptide Antigens for Potential HIV-1-Directed Vaccines. J. Am. Chem. Soc. 2013, 135, 13113-13120. [CrossRef]

48. Prabhu, S.K.; Li, C.; Zong, G.; Zhang, R.; Wang, L.-X. Comparative studies on the substrate specificity and defucosylation activity of three $\alpha$-l-fucosidases using synthetic fucosylated glycopeptides and glycoproteins as substrates. Bioorg. Med. Chem. 2021, 42, 116243. [CrossRef]

49. Zong, G.; Li, C.; Prabhu, S.K.; Zhang, R.; Zhang, X.; Wang, L.X. A facile chemoenzymatic synthesis of SARS-CoV-2 glycopeptides for probing glycosylation functions. Chem. Commun. 2021, 57, 6804-6807. [CrossRef]

50. Zong, G.; Li, C.; Wang, L.-X. Chemoenzymatic Synthesis of HIV-1 Glycopeptide Antigens. Methods Mol. Biol. 2020, $2103,249-262$.

51. Fiedler, J.D.; Brown, S.D.; Lau, J.L.; Finn, M.G. RNA-Directed Packaging of Enzymes within Virus-like Particles. Angew. Chem. Int. Ed. 2010, 49, 9648-9651. [CrossRef] [PubMed]

52. Yin, Z.; Comellas-Aragones, M.; Chowdhury, S.; Bentley, P.; Kaczanowska, K.; Benmohamed, L.; Gildersleeve, J.C.; Finn, M.G.; Huang, X. Boosting immunity to small tumor-associated carbohydrates with bacteriophage qbeta capsids. ACS Chem. Biol. 2013, 8, 1253-1262. [CrossRef] 